Гарнага О. В., к.е.н., доцент (Національний університет водного господарства та природокористування, м. Рівне)

\title{
ОСОБЛИВОСТІ СИСТЕМИ ВНУТРІШНЬОГОСПОДАРСЬКОГО ОБЛІКУ НА СІЛЬСЬКОГОСПОДАРСЬКИХ ПІДПРИЕМСТВАХ
}

У статті розглянуто роль внутрішньогосподарського обліку на сільськогосподарському підприємстві. Досліджено складові системи внутрішньогосподарського обліку - бюджетування, внутрішній контроль витрат виробництва, управлінська звітність в системі управління витратами. Висвітлено ключові проблеми та шляхи покращення внутрішньогосподарського обліку.

Ключові слова: облік; сільськогосподарське підприємство; управлінський облік; бюджетування; звітність; управління витратами.

Актуальність теми. Розвиток системи ефективного менеджменту має одне з ключових значень для продуктивного функціонування сучасного аграрного виробництва. В практичну діяльність підприємств України поняття внутрішньогосподарського (управлінського) обліку було введено Законом «Про бухгалтерський облік та фінансову звітність в Україні», де сказано, що це «..система обробки та підготовки інформації про діяльність підприємства для внутрішніх користувачів у процесі управління підприємством». Для прийняття управлінських рішень з метою забезпечення результативної діяльності підприємств необхідно завжди використовувати економічну інформацію, одержання якої забезпечує саме внутрішньогосподарський облік. Лише економічні відносини через внутрішньогосподарський облік створюють базу для швидкого підйому та значного збільшення виробництва сільськогосподарської продукції, забезпечення ії зберігання, транспортування та своєчасної реалізації.

Аналіз останніх досліджень і публікацій. Питаннями формування системи внутрішньогосподарського обліку для обробки економічної інформації та забезпечення інформаційних потреб усіх внутрішніх користувачів присвячено наукові праці багатьох вчених: Ф.Ф. Бутинця, П.М. Гарасима, Г.В. Гасенко, С.Ф. Голова, В.А. Дерія, П.В. Іванюти, В.С. Лень, В.Б. Моссаковського, Л.В. Нападовської, М.Ф. Огійчука, В.В. Сопка, М.Г. Чумаченка та ін. Однак деякі питання використання внутрішньогосподарського обліку сільськогосподарськими підприємствами лишаються дискусійними та відкритими. На сьогодні просто вести облік господарських процесів $€$ недостатнім. 
Важливо, щоб облік виконував не лише класичні інформаційну та контрольно-аналітичну функції, а й забезпечував можливість проведення планування на перспективу, сприяв узгодженій роботі усіх рівнів управління та їх взаємозв'язку з виробництвом.

Постановка завдання. Мета дослідження полягає в формуванні організаційних і методичних підходів до впровадження елементів внутрішньогосподарського обліку на сільськогосподарських підприємствах з урахуванням специфіки їх діяльності.

Викладення основного матеріалу. Так історично склалось, що бухгалтерська служба на будь-якому підприємстві має займатись суто реєстрацією господарських операцій, формувати фінансову звітність, а економічна служба - аналізувати, здійснювати розрахунки резервів виробництва та планувати діяльність. За контроль внутрішньогосподарської діяльності відповідають ревізійна чи інвентаризаційна комісії, а в окремих випадках - підрозділ внутрішнього аудиту. Усі ці функції спроможний поєднати лише внутрішньогосподарський облік. Саме він $є$ інформаційною складовою системи управління підприємством, що забезпечує керівництво економічною інформацією для прийняття управлінських рішень щодо ефективного функціонування в умовах обмежувальних виробничих ресурсів та ринкових факторів [1].

Внутрішньогосподарський облік є комплексною системою, що включає в себе безпосередньо облік витрат і виходу продукції та ряд інших об'єктів обліку, а також бюджетування й подальший контроль за діяльністю підприємства і його підрозділів та розробку заходів щодо поліпшення наслідків діяльності підприємства на ближню й далеку перспективу. Цей факт свідчить, що необхідно завжди удосконалювати систему функціонування внутрішньогосподарського обліку в Україні. Його значення полягає в тому, що він дає змогу системно розглядати в межах підприємства питання оперативного планування, аналізу, контролю та обліку окремих видів діяльності. Основним критерієм дієвої системи є ефективне управління фінансовими і трудовими ресурсами, а внутрішньогосподарський облік забезпечує для цього необхідний механізм та використовує первинну інформацію незалежно від їі кількісного виміру [2]. Запровадження внутрішньогосподарського обліку на підприємствах України потребує висвітлення трьох моментів: по-перше, уточнення функцій управлінського обліку та виконавців; по-друге, формування інформації про понесені підприємством витрати на операційні потреби, вихід продукції та результати діяльності; по-третє, здійснення відповідних організаційних заходів. 
Дослідження показують, що на більшості підприємств внутрішньогосподарський не ведеться або перебуває у початковому стані. В основному це можна пояснити відсутністю єдиної методологічної основи, методичних рекомендацій з організації такого обліку в окремих галузях вітчизняної економіки. Сьогодні вітчизняні підприємства, функціонуючи в умовах конкуренції, відчувають потребу в організації дієвої системи внутрішньогосподарського обліку. Слід зазначити, що у розвинених країнах доцільність його застосування вже не викликає сумнівів, оскільки результати досліджень свідчать про значний влив висновків управлінського обліку на підвищення ефективності показників діяльності підприємств.

На сучасному етапі розвитку найважливішим завданням $€$ вдосконалення системи управління виробництвом на основі єдиних принципів планування, оцінки, обліку, калькулювання, аналізу та контролю. У цих умовах суттєво зростає роль внутрішньогосподарського обліку, що $є$ необхідним інструментом у мобілізації всіх наявних резервів підвищення результативності виробничо-господарської і фінансової діяльності підприємств [3].

До основних принципів внутрішньогосподарського обліку, якими керуються при вимірюванні, оцінці та реєстрації господарських операцій і при відображенні їх результатів у звітності, відносять принципи безперервності, відособленості, повноти, надійності, своєчасності, співставності, зрозумілості, періодичності та економічності. Дотримання цих принципів дозволяє побудувати систему внутрішньогосподарського обліку, яка б максимально відповідала головній меті відповідного виду діяльності.

На нашу думку, під системою внутрішньогосподарського обліку на будь-якому підприємстві слід розуміти спостереження, оцінку, реєстрацію, вимірювання, обробку, систематизацію та передачу інформації переважно про витрати і результати господарської діяльності в інтегрованій системі обліку, нормування, планування, контролю та аналізу з метою формування достатньої інформаційної бази внутрішнім користувачам для прийняття оперативних і прогнозних управлінських рішень. Система внутрішньогосподарського обліку $є$ органічною частиною системи всього бухгалтерського обліку, яка забезпечує різних користувачів своєчасною, достатньою та достовірною інформацією з питань діяльності господарюючого суб'єкта. Ї̈̈ кожне підприємство може створювати, виходячи тільки зі своїх цілей та перспектив розвитку. Використання системи внутрішньогосподарського обліку сприяє вдосконаленню всього процесу управління підприємством, створює реальні можливості для його оптимізації.

Вивчення умов функціонування сільськогосподарських підпри- 
ємств України в сучасних умовах свідчить про їх істотні особливості порівняно з підприємствами інших галузей народного господарства, що впливає на побудову управлінського обліку. Ці особливості стосуються багатьох аспектів, зокрема менеджменту, економіки, технології, організації діяльності тощо (див. рисунок). Зазначені особливості діяльності сільськогосподарських підприємств впливають на процес прийняття управлінського рішення. Одночасно слід визнати, що ряд моментів визначають побудову безпосередньо обліку. Найбільш істотними серед них можна назвати такі:

- використання біологічних активів у виробничому процесі;

- наявність звітності про собівартість валової і товарної продукціï;

- наявність значної кількості статей витрат, які вважаються прямими;

- нерівномірність проведення витрат протягом виробничого періоду;

- наявність особливої групи витрат, які можна віднести до умовно-змінних [3].

Для створення ефективного внутрішньогосподарського обліку на сільськогосподарських підприємствах слід вирішити цілу низку окремих завдань [4]:

а) з'ясувати суть та визначити місце внутрішньогосподарського обліку в інформаційному забезпеченні управління сільськогосподарським виробництвом;

б) дослідити теоретико-методологічні засади розвитку внутрішньогосподарського обліку, встановити закономірності такого розвитку та можливості практичного використання його положень в обліку сільськогосподарського виробництва;

в) розробити практичні рекомендації щодо організації та методу аналітичного обліку витрат на виробництво в сільському господарстві, включаючи його управлінський аспект;

г) дослідити особливості функціонування та дієвість системи внутрішньогосподарського бюджетування як способу контролю та оцінки ефективності управлінських рішень;

д) виділити особливості застосування прогресивних методів обліку витрат в сільськогосподарських підприємствах з виробництва продукції сільського господарства та визначити напрями повнішого їх використання;

е) розробити пропозиції щодо створення та вдосконалення існуючої системи внутрішньогосподарської звітності;

ж) розробити пропозиції щодо автоматизації облікового проце- 
су та внутрішньогосподарського бюджетування для покращення обліку досліджуваних підприємств, оскільки застосування комп'ютерної техніки покращує інформаційний доступ, координацію діяльності роботи підрозділів і вирішує значне коло внутрішніх управлінських проблем підприємства.

Впровадження на сільськогосподарських підприємствах бюджетування та бюджетного планування дасть можливість контролювати витрати і керувати ними, що в кінцевому випадку дозволить підвищити ефективність виробництва сільськогосподарської продукції $[4 ; 5]$.

Сьогодні підприємства мають можливість самостійно організувати систему внутрішньогосподарського обліку та бюджетування на своєму підприємстві. Для цього їм потрібна наявність: висококваліфікованого персоналу; чітке уявлення про джерела отримання прибутку і статті витрат підприємства; взаємозв'язок між відділами підприємства; чітке уявлення процесу подальшої інтеграції управлінської інформації в бухгалтерський облік.

На нашу думку, на сільськогосподарському підприємстві доцільно складати такі бюджети: генеральний (зведений) бюджет; бюджет адміністративних витрат; бюджет витрат на збут; бюджет собівартості сільськогосподарської продукції та/або додаткових біологічних активів; бюджет собівартості реалізованої сільськогосподарської продукції та/або додаткових біологічних активів; бюджетний звіт про фінансові результати; бюджет грошових коштів; бюджетний баланс.

Організація такого планування для сільськогосподарських підприємств $є$ специфічним процесом, тому що виробництво сільськогосподарської продукції відмінне від інших видів виробництва. Наприклад, об'єктами бюджетування при виробництві молочної продукції в сільськогосподарських формуваннях можуть бути технологічні процеси, спрямовані на біологічні перетворення в молочному скотарстві в межах окремих структурних підрозділів. Предметом контролю при цьому $є$ окремі характеристики стану бюджетів, а саме: витрати кормів, дотримання ліміту фонду оплати праці, витрати палива, витрати електроенергії, надій молока та його якість тощо.

Офіційна методологія бухгалтерського обліку витрат і визначення собівартості продукції, як зазначає М.Ф. Огійчук, була побудована у відповідності до концепції і принципів, сформульованих у період планового управління економікою, коли основною метою обліку витрат було забезпечення звітних даних і калькулювання собівартості продукції. Це стосується також Методичних рекомендацій з планування, обліку і калькулювання собівартості продукції (робіт, пос- 
луг) сільськогосподарських підприємств, затверджених наказом Міністерства аграрної політики України від 6 грудня 2001 р. № 132. Названі рекомендації не повністю відповідають ринковим вимогам діяльності сільськогосподарських підприємств, спрямованих на посилення режиму економії матеріальних, трудових та фінансових ресурсів, які споживаються в процесі виробництва сільськогосподарської продукції.

Окремо слід зазначити, що сьогодні залишається відкритим питання щодо встановлення функцій внутрішнього контролю. Розглядаючи цей контроль як елемент системи управління витратами, необхідно виокремити наступні функції: 1) виявлення та використання внутрішніх резервів і посилення режиму економії; 2) виявлення резервів підвищення продуктивності праці; 3) впровадження заходів щодо зниження собівартості продукції; 4) покращення використання матеріальних, фінансових, трудових ресурсів; 5) усунення непередбачених витрат; 6) попередження крадіжок та інших правопорушень; 7) оцінка досягнутих результатів; 8) оцінка якості здійснення планування, обліку, організації, аналізу; 9) контроль за виконанням функціональних обов'язків конкретними виконавцями; 10) надання кваліфікованої допомоги управлінському персоналу.

Трансформація бухгалтерського обліку і звітності в Україні до вимог і принципів міжнародних стандартів обумовила процеси формування внутрішньої управлінської звітності. Відповідно вона стала одним із основних джерел інформаційного забезпечення управління витратами, яка готується шляхом виконання спеціальних процедур обробки, групування і підрахунку та формується на завершальній стадії облікового процесу.

Важливим кроком на етапі складання управлінської звітності $€$ розроблення її вихідних форм. Законом України «Про бухгалтерський облік та фінансову звітність в Україні» передбачено, що підприємство самостійно розробляє систему та форми внутрішньогосподарського обліку, звітності й контролю господарських операцій з метою обробки та підготовки інформації про діяльність підприємства для внутрішніх користувачів. Проте відсутність чіткого регламентування управлінського обліку в межах чинного законодавства унеможливлює побудову на практиці єдиної системи внутрішньої звітності.

Управлінська звітність $є$ узагальнюючим інструментом інформаційного забезпечення управління сільськогосподарським підприємством на всіх рівнях для прийняття ефективних рішень. На основі такої звітності приймаються рішення на всіх рівнях управління, тобто вона поряд із робочим планом рахунків $€$ основою для створення 
ефективної системи внутрішньогосподарського обліку на підприємстві.

Висновки і перспективи подальших розвідок. Практика внутрішньогосподарського обліку на сільськогосподарських підприємствах не повною мірою відповідає сучасним реаліям. 3 метою удосконалення системи внутрішньогосподарського обліку необхідно: проводити групування витрат з урахуванням функцій внутрішньогосподарського обліку; застосовувати систему формування витрат за місцями їх виникнення; здійснювати бюджетування відповідно до місць виникнення витрат на основі бізнес-процесів.

Підвищення рівня інформованості управлінського персоналу буде сприяти прийняттю виважених управлінських рішень для заходів, спрямованих на підвищення ефективності виробництва сільськогосподарської продукції та контролю за їх виконанням. Також необхідно розробити відповідні методичні рекомендації з організації внутрішньогосподарського обліку, які доповнять чинні методичні рекомендації з планування, обліку і калькулювання собівартості продукції (робіт, послуг) сільськогосподарських підприємств. Це дозволить систематизувати в одному нормативному документі основні теоретичні, методичні та організаційні положення внутрішньогосподарського обліку. 3 метою підвищення якості управління витратами сільськогосподарських підприємств запропоновано розробити на підприємстві внутрішню управлінську звітність, яка регламентує порядок формування, систему звітів про виконання бюджетів виробничих та номінальних центрів витрат і графік документообігу. Використання такої звітності дозволить адаптувати систему управління витратами до сучасних потреб забезпечення користувачів якісною інформацією.

1. Моссаковський В. Б. Управлінський облік та його особливості у сільському господарстві. Облік і фінанси АПК. 2006. № 1. С. 129-138. 2. Тлучкевич Н. Організація управлінського обліку (практика впровадження на сільськогосподарських підприємствах). Бухгалтерський облік та аудит. 2007. № 7. С. 13-25. 3. Огійчук М. Ф., Сколотій І. В. Інформаційне забезпечення управління підприємницькою діяльністю з застосуванням прогресивних форм бухгалтерського обліку. Облік і фінанси АПК. 2010. С. 50-58. 4. Огійчук М. Ф., Сколотій Л. О. Бюджетний контроль за витратами та доходами сільськогосподарської діяльності відповідно вимог П(С) БО 30 «Біологічні активи». Облік і фінанси АПК. 2006. № 10. С. 34-38. 5. Каришин Н. Бюджетування в системі бухгалтерського обліку. Галицький економічний вісник. 2010. № (26). С. 164-169. 


\section{REFERENCES:}

1. Mossakovskyi V. B. Upravlinskyi oblik ta yoho osoblyvosti u silskomu hospodarstvi. Oblik i finansy APK. 2006. № 1. S. 129-138. 2. Tluchkevych N. Orhanizatsiia upravlinskoho obliku (praktyka vprovadzhennia na silskohospodarskykh pidpryiemstvakh). Bukhhalterskyi oblik ta audyt. 2007. № 7. S. 13-25. 3. Ohiichuk M. F., Skolotii I. V. Informatsiine zabezpechennia upravlinnia pidpryiemnytskoiu diialnistiu z zastosuvanniam prohresyvnykh form bukh-halterskoho obliku. Oblik $i$ finansy APK. 2010. S. 50-58. 4. Ohiichuk M. F., Skolotii L. O. Biudzhetnyi kontrol za vytratamy ta dokhodamy silskohos-podarskoi diialnosti vidpovidno vymoh $\mathrm{P}(\mathrm{S})$ BO 30 «Biolohichni aktyvy». Oblik i finansy APK. 2006. № 10. S. 34-38. 5. Karyshyn N. Biudzhetuvannia $\mathrm{v}$ systemi bukhhalterskoho obliku. Halytskyi ekonomichnyi visnyk. 2010. № (26). S. 164-169.

Рецензент: д.е.н., доцент Осадча О. О. (НУВГП)

Harnaha 0. M., Candidate of Economics (Ph.D.), Associated Professor

(National University of Water and Environmental Engineering, Rivne)

\section{FEATURES OF THE INTERNAL ACCOUNTING SYSTEM FOR AGRICULTURAL ENTERPRISES}

The article deals with the role of farm accounting in an agricultural enterprise. The components of the system of internal accounting budgeting, internal control of production costs, management reporting in the system of cost management are investigated. The key problems and ways of improvement of business accounting are highlighted. For today, simply keeping records of economic processes is not enough. It is important that the account performs not only the classical information and control-analytical functions, but also provided the opportunity for planning for the future, contributed to the consistent work of all levels of management and their relationship with production.

Historically, accounting services at any enterprise should deal solely with the registration of economic transactions, to formulate financial statements, and the economic service - to analyze, make calculations of production reserves and plan activities. All these functions are capable of combining only the business accounting. It is an information component of an enterprise management system that provides management of economic information for making managerial 
decisions about effective functioning in the conditions of restrictive production resources and market factors.

The practice of accounting in agricultural enterprises does not fully correspond to modern realities. In order to improve the system of domestic accounting, a number of measures have been proposed. Increasing the inform level of management personnel will facilitate the adoption of effective management decisions for measures aimed at increasing the efficiency of agricultural production and monitoring it implementation.

It is also necessary to develop appropriate methodological recommendations for the organization of internal accounting, which will complement the current methodological recommendations. This will allow to systematize in one normative document the basic theoretical, methodological and organizational provisions of the internal economic accounting.

In order to improve the quality of management costs of agricultural enterprises, it is proposed to develop internal management reporting in the enterprise that regulates the procedure for formation, the system of reports on the implementation of production budgets and nominal cost centers and the schedule of workflow. Using such reporting will adapt the cost management system to the current needs of providing users with quality information.

Keywords: accounting; agricultural enterprise; managerial accounting; budgeting; reporting; cost management.

Гарнага О. Н., к.э.н., доцент (Национальный университет водного хозяйства и природопользования, г. Ровно)

ОСОБЕННОСТИ СИСТЕМЫ ВНУТРИХОЗЯЙСТВЕННОГО УЧЕТА НА СЕЛЬСКОХОЗЯЙСТВЕННЫХ ПРЕДПРИЯТИЯХ

В статье рассмотрена роль внутрихозяйственного учета на сельскохозяйственном предприятии. Исследовано составляющие системы внутрихозяйственного учета - бюджетирование, внутренний контроль издержек производства, управленческая отчетность в системе управления затратами. Освещены ключевые проблемы и пути улучшения внутри-хозяйственного учета.

Ключевые слова: учет; сельскохозяйственное предприятие; управленческий учет; бюджетирование; отчетность; управление затратами. 